\title{
PENURUNAN MISKONSEPSI SISWA MELALUI PEMBELAJARAN REMEDIAL DENGAN MENGGUNAKAN MODEL PEMBELAJARAN INDUKTIF PADA MATERI REAKSI REDUKSI DAN OKSIDASI
}

\section{STUDENT MISCONCEPTION DECREMENT THROUGH REMEDIAL LEARNING BY USING INDUCTIVE LEARNING MODEL ON THE SUBJECT OF REDUCTION AND OXIDATION REACTIONS}

\author{
Jefi $^{{ }^{*}}$, Muflihah ${ }^{1}$, Mukhamad Nurhadi $^{1,2 *}$ \\ ${ }^{I}$ Program Studi Sarjana Pendidikan Kimia, Fakultas Keguruan dan Ilmu Pendidikan, Universitas Mulawarman, \\ Samarinda, Kalimantan Timur, Indonesia \\ ${ }^{2}$ Program Studi Magister Pendidikan Kimia, Fakultas Keguruan dan Ilmu Pendidikan, \\ Universitas Mulawarman, Samarinda, Kalimantan Timur, Indonesia \\ *Corresponding Author: nurhadi1969@yahoo.co.id/jefi.chemistry15@gmail.com
}

\begin{abstract}
ABSTRAK
Penelitian bertujuan untuk menentukan penurunan miskonsepsi siswa setelah dilakukan pembelajaran remedial dengan menggunakan model pembelajaran induktif pada materi reaksi reduksi dan oksidasi (redoks) di MAN 2 Samarinda Tahun Ajaran 2016/2017. Partisipan penelitian adalah siswa kelas X MIPA 1 yang berjumlah 38 siswa dipilih menggunakan teknik purposive sampling. Pengumpulan data dilakukan melalui tes hasil belajar berupa soal yang dilengkapi butir skala certaintly of response index (CRI) pada post-test dan ulangan harian. Sebanyak 30 siswa pada post-test 1, 25 siswa pada post test 2 dan 28 siswa pada ulangan harian mengalami miskonsepsi setelah diajar menggunakan model pembelajaran langsung. Setelah dilakukan remedial menggunaan model induktif, sebanyak 24 siswa pada post test 1 , sebanyak 21 siswa pada post test 2 dan sebanyak 23 siswa pada ulangan harian mengalami miskonsepsi. Penurunan persentase miskonsepsi siswa pada post test 1 sebesar $20,0 \%$, pada post test 2 sebesar $16,0 \%$ dan pada ulangan harian sebesar $17,9 \%$. Simpulan penelitian didapatkan bahwa model pembelajaran induktif dapat mengurangi miskonsepsi siswa pada materi reaksi redoks.
\end{abstract}

Kata kunci: Miskonsepsi, pembelajaran remedial, model induktif, redoks

\begin{abstract}
This study aimed to determine the decrement of student misconception after remedial learning by using inductive learning model on the subject of reduction and oxidation (redox) reactions at MAN 2 Samarinda on the academic year 2016/2017. Research participants were tenth grade of natural science students namely students of X MIPA 1 that consist of 38 students and they were selected by suing purposive sampling technique. Data collection was done through the test of learning outcomes in the form of questions aided with items of scale certaintly of response index (CRI) in post test and subject final examination. A total of 30 students at post-test 1,25 students at post test 2 , and 28 students at subject final examination have misconception after they taught using direct learning. After they taught using inductive learning model, 24 students at post-test 1,21 students at post test 2 , and 23 students at subject final examination have misconception. Decrements of student misconception percentage at post test 1 , post test 2 , and subject final examination were $20.0,16.0$, and $17.9 \%$, respectively. So the remedial learning
\end{abstract}


using inductive learning model could decrease student misconception on the subject of redox reaction.

\section{Keywords: Misconception, remedial learning, inductive model, redox}

\section{PENDAHULUAN}

Pembelajaran kimia di sekolah menengah atas pada saat sekarang ini telah mengalami banyak perubahan terutama pada kesiapan siswa dalam mengasimilasikan ilmu yang diserapnya dalam proses pembelajaran. Ilmu yang ditransfer kepada siswa pada proses pembelajaran, nantinya akan diolah secara runtut dan sistematis pada memori siswa. Selama proses kegiatan mengajar berlangsung tentu ditemukan berbagai kendala yang terjadi dalam mencapai tujuan mencerdaskan pengetahuan akademik siswa. Siswa seringkali mengalami kegagalan paham dalam menerima konsep-konsep ilmu pengetahuan atau yang disebut sebagai gejala miskonsepsi pembelajaran (Maulan, 2011). Gejala miskonsepsi terjadi dikarenakan siswa tidak bisa mengasimilasikan konsep-konsep pengetahuan yang baru diperoleh dengan pengetahuan konsep awal yang sebelumnya sudah ada dalam benak siswa. Selain itu terdapat beberapa faktor lainnya yang juga turut andil dalam menyebabkan miskonsepsi siswa terjadi yakni faktor guru, faktor siswa dan faktor metode pembelajaran yang digunakan (Berg, 1991).

Pemilihan model pembelajaran sangat berperan penting dalam mensukseskan kegiatan pembelajaran di dalam kelas. Setiap model pembelajaran tentu memiliki ciri-ciri langkah pembelajaran yang berbeda. Melalui penggunaan model pembelajaran yang efektif dan berbasis membangun pengetahuan dari konsep dasar, maka diharapkan pengetahuan yang diperoleh siswa akan bersifat utuh dan permanen. Salah satu model pembelajaran yang dapat diterapkan dalam mengatasi permasalahan tersebut adalah model pembelajaran induktif. Model pembelajaran induktif merupakan model pembelajaran yang berkaitan dengan pembangunan pengetahuan konsep melalui metode ceramah, tanya jawab dan diskusi. Model pembelajaran induktif dapat mengembangkan pemikiran siswa yang dikarenakan terdapat proses kegiatan observasi, membandingkan, mengidentifikasi serta menggeneralisasikan suatu pola atau konsep. Melalui model pembelajaran induktif, siswa akan dibimbing untuk menemukan dan memahami suatu konsep berdasarkan ilustrasi contoh dan non-contoh yang diberikan oleh guru (Nurfadilla, 2013).

Berdasarkan hasil penelitian sebelumnya, kegiatan pembelajaran pada materi perubahan fisika dan perubahan kimia dengan menggunakan model induktif dapat membuat keterlaksanaan kegiatan proses belajar mengajar menjadi sangat baik. Hasil angket respon siswa menyatakan hampir keseluruhan siswa memberikan respon sangat baik terhadap penerapan pembelajaran induktif. Berdasarkan hasil tes miskonsepsi yang dilakukan juga didapatkan adanya penurunan persentase miskonsepsi siswa secara keseluruhan setelah diterapkan pembelajaran model induktif yakni sebesar 23,95\% (Nilia, 2014).

Berdasarkan permasalahan yang dipaparkan, penulis tertarik untuk meneliti tentang pengurangan miskonsepsi siswa melalui penggunaan model pembelajaran induktif pada pokok bahasan reaksi redoks di kelas X MIPA 1 MAN 2 Samarinda tahun ajaran 2016/2017.

\section{METODE PENELITIAN}

Jenis penelitian ini adalah penelitian praeksperimen yang menggunakan desain one group pre-test and post-test design. Partisipan dalam penelitian ini adalah 38 siswa kelas X MIPA 1 MAN 2 Samarinda yang dipilih dengan teknik purposive sampling. Penelitian dilaksanakan pada tanggal 23 Januari 2017 sampai 6 Maret 2017 pada tahun ajaran 2016/2017. Teknik pengumpulan data dilakukan dengan menggunakan teknik tes dan teknik non tes berupa observasi yang digunakan sebagai data pendukung. Data miskonsepsi siswa diperoleh dari kegiatan post test dan ulangan harian yang dilakukan pada setiap akhir pembelajaran. Jawaban siswa dianalisis menggunakan metode CRI dengan butir skala tingkat keyakinan rentang $0-5$ (Tayubi, 2005). Hasil jawaban siswa yang benar atau salah dengan butir skala CRI antara $0-2$ menandakan siswa mengalami tidak paham konsep. Hasil jawaban siswa yang salah dengan butir skala CRI antara $3-5$ menandakan siswa mengalami miskonsepsi. Hasil jawaban siswa yang benar dengan butir skala CRI antara $3-5$ menandakan 
siswa mengalami paham konsep. Metode analisis data yang digunakan dalam penelitian adalah analisis deskriptif kuantitatif yang dilakukan untuk mengetahui adanya pengurangan persentase siswa yang mengalami miskonsepsi setelah dilakukan pembelajaran remedial model induktif. Besaran persentase penurunan miskonsepsi siswa (X) didapatkan melalui perhitungan dengan menggunakan persamaan (1)

$$
\mathrm{X}=\frac{\mathrm{MK}_{\text {awal }}-\mathrm{MK}_{\text {akhir }}}{\mathrm{MK}_{\text {awal }}} \times 100 \%
$$

Tabel 1

Sebaran jumlah siswa setelah dites menggunakan

\begin{tabular}{lcccccc}
\multicolumn{3}{c}{ Soal yang dilengkapi dengan CRI } \\
\hline \multirow{3}{*}{ Tes } & \multicolumn{3}{c}{$\begin{array}{c}\text { Model pembelajaran } \\
\text { langsung }\end{array}$} & \multicolumn{3}{c}{$\begin{array}{c}\text { Remedial, model } \\
\text { pembelajaran induktif }\end{array}$} \\
\cline { 2 - 7 } & TP & Mis & PK & TP & Mis & PK \\
\hline Post test 1 & 3 & 30 & 5 & 0 & 24 & 14 \\
Post test 2 & 4 & 25 & 7 & 0 & 21 & 17 \\
Ulangan & 4 & 28 & 6 & 0 & 23 & 15 \\
harian & & & & & &
\end{tabular}

Keterangan: $\mathrm{TP}=$ tidak paham konsep, Mis = miskonsepsi, $\mathrm{PK}$ = paham konsep
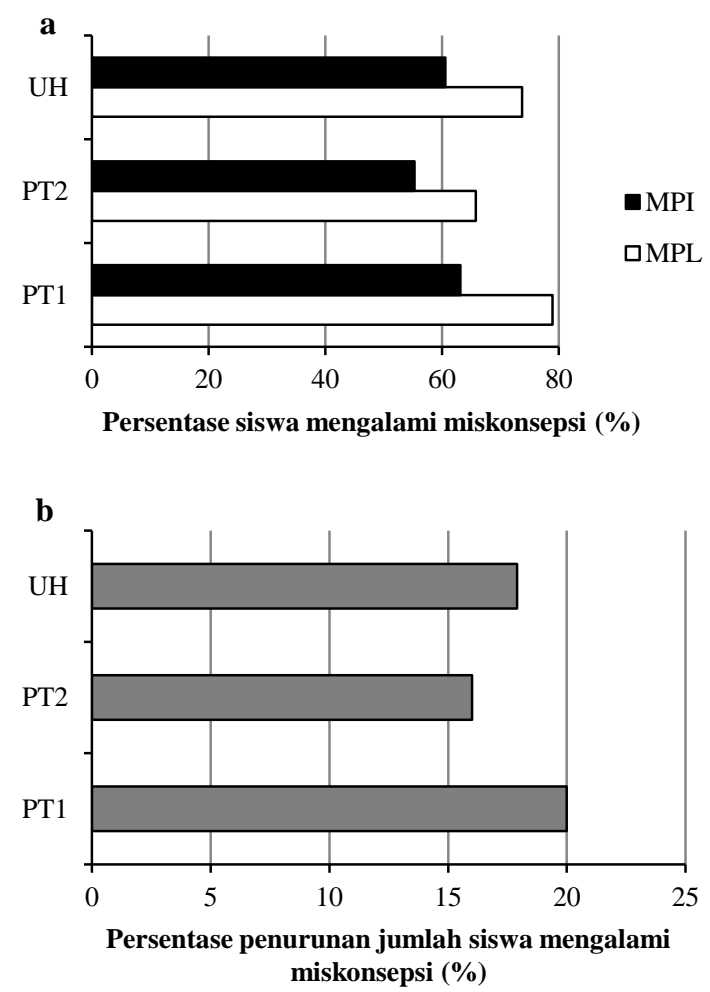

Gambar 1. (a) Persentase siswa yang mengalami miskonsepsi, (b) Persentase penuruan siswa miskonsepsi, MPI $=$ model pembelajaran induktif, MPL $=$ model pembelajaran langsung, $\mathrm{PT} 1=$ post test $1, \mathrm{PT} 2$ = post test $2, \mathrm{UH}=$ ulangan harian dimana $\mathrm{MK}_{\text {awal }}$ adalah jumlah siswa yang mengalami miskonsepsi pada pembelajaran dengan model pembelajaraan langsung dan $\mathrm{MK}_{\mathrm{akhir}}$ adalah jumlah siswa yang mengalami miskonsepsi setelah diajar dengan model pembelajaran induktif.

\section{HASIL DAN PEMBAHASAN}

Remedial dapat menurunkan miskonsepsi siswa tentang suatu konsep. Data miskonsepsi siswa, persentase miskonsepsi siswa dan penurunan miskonsepsi siswa tentang konsep reaksi redoks sebelum dan sesudah diberikan pembelajaran remedial menggunakan model pembelajaran induktif disajikan pada tabel 1, gambar 1 dan 2. Dari data tersebut tampak bahwa pembelajaran remedial menggunakan model pembelajaran induktif dapat menurunkan miskonsepsi siswa tentang konsep reaksi redoks.

Model pembelajaran yang berbasis rekonstruksi pengetahuan siswa lebih efektif dalam menanamkan pemahaman konsep pada struktur memori siswa. Pembangunan konsep dalam kegiatan pembelajaran tidak hanya berpusat pada faktor guru dan siswa, terdapat juga faktor dari model pembelajaran yang turut andil dalam memudahkan proses transfer ilmu kepada siswa. Penggunaan model pembelajaran yang menarik dalam pelaksanaanya akan membuat siswa menjadi termotivasi dan aktif dalam mengikuti alur kegiatan belajar mengajar.

Penelitian ini menggunakan dua model pembelajaran yang berbeda yakni model pembelajaran langsung dan model pembelajaran induktif. Secara umum dalam teknis pelaksanaannya kedua model tersebut sama-sama dilaksanakan dengan menggunakan metode ceramah yang disampaikan secara langsung kepada siswa, tetapi jika dilihat dari tahapan-tahapan atau sintaks kegiatan pembelajaran terdapat perbedaan yang jelas pada kedua model pembelajaran tersebut. Kegiatan pembelajaran model langsung memiliki lima sintaks pembelajaran yakni tahap penyampaian tujuan pembelajaran, tahap penyampaian informasi, tahap bimbingan latihan, tahap pengecekan pemahaman siswa dan tahap pemberian latihan soal (Bahri, 2006). Kegiatan pembelajaran pada tahap penyampaian informasi dilakukan dengan menggunakan metode penyampaian ceramah secara langsung terhadap siswa. Kegiatan penyampaian materi ajar hanya dilakukan secara satu arah dan 
cenderung monoton yang menyebabkan siswa menjadi pasif. Hal tersebut membuat konsep-konsep materi pembelajaran yang ingin ditanamkan guru dalam struktur memori siswa hanya dipahami sebagian. Sehingga membuat siswa mendapatkan pengetahuan awal yang salah pada tahap penyampaian informasi yang terus berlanjut pada tahap kegiatan pembelajaran selanjutnya. Siswa cenderung mengalami miskonsepsi belajar.

Kegiatan pembelajaran model induktif juga memiliki lima sintaks pembelajaran yakni tahap pendahuluan, tahap pembangunan konsep, tahap pengarahan konsep, tahap pengembangan konsep dan tahap aplikasi (Nurhadi \& Senduk, 2004). Kegiatan pembelajaran diawali dengan tahap pendahuluan yakni guru menampilkan sebuah ilustrasi peristiwa kimia dalam kehidupan seharihari. Selanjutnya dalam tahap pembangunan konsep, siswa mulai melakukan pengamatan untuk menemukan pola-pola dalam ilustrasi atau gambar yang telah ditampilkan. Siswa juga berupaya untuk menemukan karakteristik hubungan contoh yang telah ditampilkan dengan materi pembelajaran yang dipelajari. Adanya kegiatan pengamatan akan membuat siswa menjadi aktif dan tertarik dalam memulai pembangun konsep pengetahuan dari tingkat dasar. Selain itu kegiatan pembelajaran terasa lebih bermakna dikarenakan terdapat hubungan timbal balik antara guru dan siswa. Kesalahan siswa dalam menafsirkan konsep diperbaiki guru dalam tahap pengarahan konsep dan pengembangan konsep, tahap ini guru menyampaikan konsep pembelajaran kembali tetapi tidak hanya menggunakan metode ceramah tetapi juga menggunakan metode diskusi dan tanya jawab. Adanya kegiatan diskusi dan tanya jawab membuat pembelajaran yang dilakukan berlangsung secara timbal balik dan terjadi proses asimilasi pengetahuan konsep dari guru dengan prakonsepsi siswa. Tahap terakhir yakni tahap aplikasi yang digunakan guru untuk menguji pemahaman konsep siswa melalui kegiatan post test dan ulangan harian.

Gambar 1 menampilkan adanya perbandingan jumlah siswa yang mengalami miskonsepsi tentang rekasi redoks antara siswa yang diajar sebelum remedial (diajar menggunakan model pembelajaran langsung) dan siswa yang diajar dengan remedial menggunakan model pembelajaran induktif. Terjadinya penurunan miskonsepsi siswa menandakan model pembelajaran induktif lebih efektif dari model pembelajaran langsung dalam membangun konsep pengetahuan dan meningkatkan hasil belajar siswa.

Hasil analisis perhitungan didapatkan terjadi pengurangan persentase miskonsepsi siswa secara keseluruhan (gambar 2). Berdasarkan hasil analisis perhitungan diperoleh penurunan miskonsepsi siswa setelah dilaksanakannya pembelajaran remedial dengan menggunakan model induktif yakni pada post test 1 sebesar $20,00 \%$, pada post test 2 sebesar $16,00 \%$ dan pada ulangan harian sebesar $17,86 \%$. Simpulan akhir dapat dikatakan model pembelajaran model induktif dapat diterapkan sebagai salah satu solusi dalam mengatasi adanya kendala miskonsepsi belajar siswa pada materi reaksi redoks. Perlu dilakukan penelitian kembali dengan menggunakan model pembelajaran induktif yang dikolaborasikan dengan metode dan media pembelajaran yang sesuai, sehingga beberapa siswa yang masih mengalami gejala miskonsepsi pada pembelajaran dapat dikurangi seminimal mungkin atau tidak ada sama sekali.

\section{SIMPULAN}

Pengurangan miskonsepsi siswa melalui pembelajaran remedial pada pokok bahasan reaksi redoks di kelas X MIPA 1 MAN 2 Samarinda dapat terjadi dengan menggunakan model pembelajaran induktif.

\section{UCAPAN TERIMAKASIH}

Penulis mengucapan terimakasih kepada Bapak Saharuddin, M.Pd. selaku kepala MAN 2 Samarinda yang telah memberikan izin dan membantu penulis selama proses pengambilan data penelitian.

\section{DAFTAR PUSTAKA}

Bahri, S. 2011. Strategi Belajar Mengajar. Jakarta: Bumi Aksara.

Berg, E.V.D. 1991. Miskonsepsi Fisika dan Remediasi. Salatiga: Unipress Kristen Satya Wacana.

Maulan, A. 2011. Identifikasi miskonsepsi calon guru kimia pada konsep (pembelajaran) ikatan kimia SMA Kelas X pada mata kuliah telaah kurikulum. Skripsi. Samarinda: Universitas Mulawarman.

Nilia, D.I.M. dkk. 2014. penerapan pembelajaran induktif untuk mereduksi miskonsepsi pada 
materi perubahan fisika dan perubahan kimia. Pensa e-Jurnal: Pendidikan, 2(2), 223-240.

Nurfadilla, A.I. 2013. Pengaruh media grafis melalui pembelajaran induktif materi aliran energi dalam ekosistem di Kelas VII. Pensa e-Jurnal: Pendidikan, 1(1), 30-34.

Nurhadi, Y. dan Senduk, A.G. 2004. Pembelajaran kontekstual (contextual teaching and learning/TCL) dan penerapannya dalam $K B K$. Malang: UMPress.

Tayubi, Y.R. 2005. Identifikasi miskonsepsi pada konsep-konsep fisika menggunakan certainly of respon index (CRI). Mimbar Pendidikan, 3(24), 4-9. 